\title{
Between overstocking and extinction: conservation and the intensification of uneven wildlife geographies in Africa
}

\author{
Bram Büscher ${ }^{1}$ \\ Wageningen University, The Netherlands \\ Stellenbosch Institute for Advanced Study, Republic of South Africa \\ University of Johannesburg, Republic of South Africa
}

\begin{abstract}
Conservation news from Africa generally seems to exude crisis. Over the last decade, especially, we have witnessed the increasingly visible decline of charismatic species such as the rhino, elephant, cheetah, lion, giraffe and others, coupled with an ongoing defaunation of many forested areas. What is much less visible is that in certain areas an important countertrend is also occurring: the growth of wildlife species, most notably through the stocking of private lands and initiatives to develop broader wildlife economies. This article explores these two trends and shows that they are key in understanding conservation in sub-Sahara Africa and its rapidly changing political economy more generally. Focusing on South Africa, especially the booming wildlife economy in the Greater Kruger area, the article argues that the private possession or commodified management of conservation spaces and its (over)stocking of species actually benefits from an overall decline of charismatic species. As the number of charismatic species declines across the continent, it increases the value of wellstocked, privately conserved lands, providing their owners with unique sources of profit and revenue. The result is an intensification of uneven wildlife geographies across Africa.
\end{abstract}

Keywords: Charismatic species, extinction, Africa, conservation, wildlife

\section{Résumé}

Les nouvelles sur la conservation en Afrique semblent généralement exhaler la crise. Au cours de la dernière décennie, en particulier, nous avons assisté au déclin de plus en plus visible d'espèces charismatiques telles que le rhinocéros, l'éléphant, le guépard, le lion, la girafe et d'autres, couplé à une défaunation continue de nombreuses zones forestières. Ce qui est beaucoup moins visible, c'est que dans certaines régions, une contretendance importante se produit également: la croissance des espèces fauniques, notamment sur les terres privées. Ceux-ci ont également développé des économies plus larges et environnantes de la faune. Cet article explore ces deux tendances et montre qu'elles sont essentielles pour comprendre la conservation en Afrique subsaharienne et son économie politique, qui évolue rapidement. En se concentrant sur l'Afrique du Sud, en particulier l'économie de la faune en plein essor dans la région du Grand Kruger, l'article soutient que la possession privée d'espaces de conservation bénéficie en réalité d'un déclin global des espèces charismatiques. À mesure que le nombre d'espèces charismatiques diminue à travers le continent, cela augmente la valeur des terres bien approvisionnées et conservées de manière privée, offrant à leurs propriétaires des sources uniques de profit et de revenus. Le résultat est une intensification des géographies inégales de la faune à travers l'Afrique. Mots-clés: Espèces charismatiques, extinction, Afrique, conservation, faune sauvage

\footnotetext{
${ }^{1}$ Prof. Bram Büscher, Professor and Chair, Sociology of Development and Change, Wageningen University, The Netherlands; Fellow, Stellenbosch Institute for Advanced Study, Wallenberg Research Centre at Stellenbosch University, South Africa; Visiting Professor, Department of Geography, Environmental Management and Energy Studies, University of Johannesburg, South Africa. Email: bram.buscher "at" wur.nl. Acknowledgements: thanks to two reviewers, Stasja Koot, Lerato Thakholi, Sierra Deutsch and the participants at the Crisis Conservation workshop held from 5-9 October 2020, and Simon Batterbury for helpful comments and suggestions on different versions of the article. The workshop and the research for this article were made possible by an NWO-VIDI grant (nr. 425-14-001). This is the fourth article in Bram Büscher (ed.). 2021. "Political ecologies of extinction", Special Section of the Journal of Political Ecology 28: 696-888.
} 


\section{Resumen}

Las noticias sobre la conservación de la vida silvestre en África anuncian su estado de crisis. Particularmente durante la última década, se ha constatado la disminución de las poblaciones de especies carismáticas como el rinoceronte, el elefante, el guepardo, el león o la jirafa, vinculada a la defaunación de muchas áreas forestales. Por otro lado y de manera menos llamativa, ciertas áreas muestran una tendencia contraria, con el incremento de poblaciones de especies silvestres, mediante la repoblación de terrenos de propiedad privada en los que se desarrollan modelos económicos vinculados a la vida silvestre. Este artículo explora estas dos tendencias, por su valía para comprender la conservación en el África subsahariana, así como los cambios acaecidos en su economía política. Centrándonos en Sudáfrica, especialmente en la pujante economía basada en la vida silvestre en el área circundante del Parque Nacional Kruger, el artículo demuestra que la propiedad privada o la gestión mercantilizada de los espacios de conservación y su (sobre)repoblación de especies, en realidad, se aprovecha de la disminución generalizada de las especies carismáticas. Así sucede que el valor de las tierras repobladas y gestionadas por particulares aumenta a medida que disminuye el número de especies carismáticas en todo el continente, proporcionando fuentes de ingresos y de beneficios a sus propietarios. La consecuencia final es la intensificación de las geografías desiguales de la vida silvestre en África.

Palabras clave: Especies carismáticas, extinción, África, conservación, vida silvestre

\section{Introduction}

Conservation dynamics across the African continent have long been volatile. And they seem to have become even more so in recent years. Several trends stand out in this respect. The first is the increasingly visible decline of charismatic species. During the 2016 Conference of Parties (COP) of the Convention on International Trade in Endangered Species of Wild Fauna and Flora (CITES) ${ }^{2}$ and the months that followed, much alarming news came out about rapidly declining numbers of species such as the cheetah, lion and giraffe. At the same time, there has been much attention on the rapid increase of wildlife crime over the last decade, globally but especially in Africa related to the poaching of elephants and rhinos (Duffy et al. 2019). That said, the fact that many African species are facing difficulties is old news. For years, scientists have stated that many species have historically and more recently seen large declines, even in protected areas (Oates 1999; Cragie et al. 2010). They would add that this decline is highly uneven across the continent and that there are important exceptions and even successes as well (Barnes et al 2016). But some of the recent declines are considered more alarming than normal, such as the rapid decline of giraffes and cheetahs: numbers for both have dropped by roughly $40 \%$ across the continent. Combined with the rise in militant wildlife crime, these dynamics have given further impetus to the argument that we are currently living through the sixth mass extinction of species (Barnosky et al. 2011; Ceballos et al. 2015)

A second important conservation trend over the last decade is one that is much less globally publicized in news outlets and currently not yet very widespread across the continent. This is the growth in numbers of some wildlife species, most notably on private lands and stimulated by industries like wildlife ranching and tourism. Mainly in selected biodiverse pockets in Southern and Eastern Africa and especially in South Africa, the establishment of private parks, so-called 'wildlife estates' or the de facto privatization of (parts of) public parks has been steadily growing (Child 2004). These dynamics conjoin a more general rise in interest in the 'wildlife economy' and the trade in wildlife species within and between countries (Department of Environmental Affairs 2016; Driver et al. 2019). As a result, there have also been countertrends in the regional growth of certain wildlife species, including several of the ones mentioned above. Some of this growth has been so substantial that wildlife management measures are regularly taken to bring population numbers down for fear of areas becoming 'overstocked', which would degrade ecosystems and hence be detrimental to the wildlife itself.

This article argues that these two seemingly contradictory trends tell a larger and important story about conservation and the extinction crisis in Africa. They are, in fact, key to understanding the current political economy of conservation on the continent, and even the political economy of Africa more broadly. Both the decline and fear of extinction of species and growth in specific pockets are part of a new phase in the integration

\footnotetext{
${ }^{2}$ Which was held from 24 September to 5 October 2016 in Johannesburg, South Africa.
} 
of the African continent into the global capitalist economy. In South Africa, this has advanced the farthest and it therefore makes sense to look at dynamics here as a potential window to what might happen elsewhere. I do so with great caution and not with an aim to make any (straightforward) comparison between South Africa and the rest of the continent. One could perhaps assume that some trends in South Africa might be mirrored in other African countries with large wildlife populations such as (parts of) Namibia, Botswana, Zambia, Zimbabwe, Tanzania Uganda and Kenya. Yet, it may also be that South Africa remains fairly unique in this respect.

What is clear is that in the 'uneven historical and geographical development' of the continent, it so happens that South Africa is both highly biodiverse and the most developed country on the continent, giving it particular abilities and possibilities that allow it to further profit from wildlife. By focusing on the Greater Kruger area and especially the booming wildlife town of Hoedspruit, the article argues that the private possession or commodified management of conservation spaces and its (over)stocking of species actually benefits from an overall decline of charismatic species in the continent as a whole. As the number of charismatic species declines across the continent, it increases the value of well-stocked, privately conserved lands, providing their owners with unique sources of profit and revenue.

In order to develop this argument, I will first go into a discussion of species decline dynamics within extinction discourses regarding Africa, after which I will connect the two contradictory dynamics in general and through a case-study of the Hoedspruit area within the great Kruger region as the most important centre of the wildlife economy in South Africa. ${ }^{3}$ Next, I will endeavour to make sense of these dynamics and the role of the Hoedspruit case study by discussing these as part of an overall intensification of uneven wildlife geographies across the continent. I conclude by reflecting on the implications of the central argument and calling for more research and reflection on political ecologies of extinction.

\section{Species decline and extinction fears}

Debates on species numbers in Africa are fraught with tensions, contradictions, and contestations. Despite this, scientists, conservation organizations, governments and others continuously study and communicate the dynamics around species numbers and populations, particularly as these are becoming more volatile due to the intensifying uneven geographical development of the continent. As argued by UNEP's most recent regional environmental assessment:

Land, which is one of Africa's most prized natural assets, is under increasing pressure stemming from competition for access, changing global and regional consumption patterns, and the drive for greater economic growth. These pressures are leading to its degradation, loss of access, inequity and encroachment on fragile and protected ecosystems. (UNEP 2016: 15)

These and other pressures have, over the last decades, according to Craigie et al. (2010: 2221), led to a 59\% decline in large mammal populations in protected areas across the continent. Crucially, they add that "Indices for different parts of Africa demonstrate large regional differences, with southern African PAs typically maintaining their populations and western African PAs suffering the most severe declines." Other studies come to similar conclusions, arguing that protected areas are important for many species and that "wildlife population trends are more positive in PAs located in countries with higher development scores, and for larger-bodied species" (Barnes et al. 2015: 1). Based on this, Barnes et al. (2015: 1) conclude that "the link between wildlife trends and national development shows that the social and economic conditions supporting PAs are critical for the successful maintenance of their wildlife populations." This bodes well in particular for South Africa, even though the country has its fair share of threatened and endangered species, and pressures on them (Republic of South Africa 2014: 10-16).

\footnotetext{
${ }^{3}$ The article builds on research done in a five year, NWO (Netherlands Organisation for Scientific Research) funded project (452-14-001), as well as on my long-term research in the Kruger area since 2003. Since 2016, I have made six research trips to Hoedspruit and the Kruger area, and conducted over 25 in-depth interviews, engaged in participatory observation in wildlife estates, reserves and the town itself, and collected archival material and relevant documents for discourse analysis.
} 
My aim in this Section is not to provide an assessment of the methodological debates in ecology and conservation biology on species numbers and trends in Africa or generally. What is clear from the literature, though, it that there is limited consensus on most species' numbers, while there is a major bias in how research and popular attention and funding tend to go to a relatively small set of (often charismatic or otherwise popular) species (Donaldson et al. 2016; Davies et al. 2018; Gordon et al. 2019). There is, moreover, a major 'plant blindness' (Balding and Williams 2016) in conservation research, which is also reflected in the current article. Most importantly, the ecological literature laments that little is known about how trends in species numbers relate to broader patterns of development. As indicated Di Marco and colleagues (2018: 2): the "major limitation in these analyses is the absence of a link to spatial and temporal changes in human pressure and how these lead to change in the risk of species declines." These authors propose measuring and modelling broader concepts like the 'human footprint' to address this limitation, though they also acknowledge that this can provide potential indications of risk only (see also Isbell et al. 2017).

Instead, as a political ecologist, I want to place several striking features and disagreements in ecological debates on species trends in context, especially in relation to broader extinction fears and political economic developments across the continent, including the above assertion by Barnes and colleagues about trends being more positive in 'countries with higher development scores.' If there would be a direct correlation between 'higher development scores' and more positive wildlife numbers, then the above UNEP assessment may be something temporary and nothing to worry about for the long-term as long as the continent continues to 'develop.' This correlation, however, is deeply problematic. First, this is because globally, many highly developed countries are not necessarily known for their 'positive wildlife numbers', including many countries in Europe. Second, it leaves out broader contexts and other dynamics that complicate any notion of correlation. This includes the Intergovernmental Science-Policy Platform on Biodiversity and Ecosystem Services (IPBES) report from 2019, which concluded that over a million species risk extinction in the near future globally, and the 2020 global SARS-CoV-2 pandemic that has rendered wildlife conservation in Africa even more uncertain, particularly through the massive decrease in funding (Lindsey et al. 2020; Fletcher et al. 2020). Hence a more robust analysis of the link between species dynamics and 'development scores' is needed.

Within this context of 'extinction fears', the key question is how to evaluate the debate on species numbers in Africa? A brief look at several high-profile species will help to clarify why a focus on the above two main trends in a broader political-economic context is important to answer this question. First: the lion (Panthera leo). As one of the most charismatic of all African animals, lion population dynamics have been studied and debated for a long time. The scientific consensus seems to be that lion numbers and its overall genetic diversity are on a steady decline (Bauer et al. 2015; Dures et al. 2019). A recent, continent-wide analysis argues that "lion populations are rapidly disappearing from large parts of Africa, signaling a major trophic downgrading of savannah ecosystems" (Bauer et al. 2015: 14894). They show that West and Central African lion populations have been hardest hit but also that "lion conservation is successful in southern Africa, in part because of the proliferation of reintroduced lions in small, fenced, intensively managed, and funded reserves" (idem). This, they indicate, brings its own genetic and metapopulation challenges, thus concluding that "unless political and funding commitments are scaled up to address mounting levels of threat, lions may disappear from most of Africa" (Bauer et al. 2015: 14897).

This gloomy analysis received a response from other ecologists contesting some of its main premises. Riggio et al (2016: E107) argue that Bauer et al.'s "own data (...) rejects their claims that lions are "declining everywhere, except in four southern countries" and that lions increase only where "intensively managed."' They argue that even in Central and West Africa there are stable lion populations, that data from two sites have been misinterpreted and that Bauer et al.'s claims in favor of fencing do not hold. Most importantly, they conclude that:

Certainly, serious threats are mounting and demand attention. That said, it is premature, indeed inappropriate, to level blanket criticism at countries outside southern Africa. The data show that authorities have maintained effective protection for many lion populations and should be congratulated where they have succeeded. Conservationists should also be wary of overstating widespread declines. If such claims are later rejected, science loses credibility. Conservation 
needs transparency in methods and data, and honest appraisal of the evidence and considerable uncertainties. Bauer et al. have not satisfied these essential requirements. (Riggio et al. 2016)

Interestingly, this critique seems to suggest that Bauer and colleagues, who are some of the world's most revered lion researchers, have given in to extinction fears and allowed their analysis to become overtly negative towards the 'decline side.' Such, indeed, that it not only needed rectification but also a stern critique to protect scientific credibility.

Another interesting case in terms of wildlife declines and extinction fears relates to the Giraffe. Giraffes are generally not poached in great numbers, and hence their numbers depend on available land where they can thrive. According to the latest IUCN red list assessment in 2016, the global population status had to be adjusted from 'least concern' to 'vulnerable' "due to an observed, past (and ongoing) population decline of $36-40 \%$ over three generations (30 years, 1985-2015)." Responding to this news in 2016, Julian Fennessy, then co-chair of the IUCN giraffe and okapi specialist group, stated that "whilst giraffes are commonly seen on safari, in the media and in zoos, people - including conservationists - are unaware that these majestic animals are undergoing a silent extinction. It is timely that we stick our neck out for the giraffe before it is too late." ${ }^{5}$ Responding to the same news, famous conservationist David Attenborough argued: "these gentle giants have been overlooked. It's well known that African elephants are in trouble and there are perhaps just under half a million left. But what no one realised is there are far fewer giraffes, which have already become extinct in seven countries." 6

More recently, at the Conference of Parties of the Convention on the Conservation of Migratory Species of Wild Animals (CMS), held in February 2020 in India, a press release was sent out urging for an "Africawide conservation strategy for Giraffe." It started as follows: "A century ago, more than one million Giraffe used to roam across sub-Saharan Africa. But these gentle giants are now extinct in at least seven countries with only 100,000 animals remaining in fragmented populations across the continent." It goes on to paint a grim picture:

Infrastructure development such as roads, railways, powerlines, and pipelines have created barriers to migration, fragmenting Giraffe populations and their habitats. Habitat loss and degradation have also been fuelled by wildfire, livestock incursions and illegal encroachment by humans. Poaching, snaring and trade for bushmeat, skins, tails and traditional medicine have further put the Giraffe's survival in doubt. Diseases, civil unrest, climate change, human population growth, lack of law enforcement, and lack of awareness of Giraffe conservation exacerbate these threats. ${ }^{7}$

Species decline here is, again, accompanied by stark extinction fear discourses. But is this warranted? An official document submitted by the South African government to the August 2019 CITES CoP on the status of the Giraffe in South Africa argues that "the South African giraffe (Giraffa camelopardalis giraffa) can be hailed as a southern African conservation success story." It goes on to state that:

The South African giraffe is considered a common species within South Africa, with an estimated population of between 21,053 and 26,919 individuals. Approximately half of the population occurs on privately-owned land (...). Since the 1960s, wildlife numbers on South African commercial farms have continued to rise, as has their economic value (...). In the early 1980s there were approximately 250 privately-owned giraffes in South Africa, but following their introduction into numerous private and provincial game reserves (reserves managed by

\footnotetext{
${ }^{4}$ https://www.iucnredlist.org/species/9194/136266699\#assessment-information, accessed 25 February 2020.

5 https://www.theguardian.com/environment/2016/dec/08/giraffe-red-list-vulnerable-species-extinction, accessed 25 February 2020.

${ }^{6}$ Idem. See also: https://www.theatlantic.com/magazine/archive/2020/04/how-to-tackle-a-giraffe/606787/, accessed 19 August 2020.

${ }^{7}$ https://www.cms.int/en/news/africa-wide-conservation-strategy-giraffe, accessed 25 February 2020.
} 
government nature conservation authorities; ...) it is now estimated there are giraffes on most of South Africa's estimated 12,000 game farms and ranches. Populations on these properties comprise between one and 250 individuals, with a mean of 30 individuals per property. ${ }^{8}$

The note further argues that there are no significant threats to Giraffes and that the population trend is precisely opposite to those in earlier-cited discourses:

The population of Giraffa camelopardalis giraffa in South Africa is increasing. Data from 13 formally protected areas show an estimated population increase of $54 \%$ over three generations (1985-2015) (...). By 2013, the number of giraffes in the Kruger National Park had increased by approximately 150\% from the 1979 estimate. An even greater increase occurred on many of the estimated 12,000 privately-owned game ranches, indicating that private ownership can help to conserve the subspecies. The increase in private ownership of giraffes across South Africa and the economic interest in conserving a thriving, healthy and viable population, and by default a suitable environment for giraffes, have stimulated an increase in giraffe numbers within South Africa. ${ }^{9}$

While it cannot be stated that the strong increase in Giraffe numbers in one country is good news for Giraffes across Africa as a whole, this evidence does indicate that Giraffes undergoing a 'silent extinction' is exaggerated. One could perhaps argue that the confinement of a growing sub-population of the species may lead to genetic 'bottlenecking', where genetic diversity or major shocks could still lead to sudden implosion in numbers. Yet, researchers believe that this is extremely unlikely: after acknowledging and assessing these risks, Deacon and Tutchings (2019: 47) conclude their article on this 'conservation success story' as follows: "The increase in private ownership of giraffes across South Africa and the economic interest in conserving a thriving, healthy and viable population, and by default a suitable environment for giraffes, have stimulated an increase in giraffe numbers."

Other charismatic species also show uneven dynamics. The African wild dog seems to be decreasing across most of their range, though again not in South Africa where populations in private reserves, especially, are increasing (Nicholson 2020). Endangered mountain gorilla numbers in Uganda and Rwanda have been on the increase recently, despite many odds. ${ }^{10}$ Elephant numbers seem to have taken a big hit between 2008 and 2017, with a decrease of over 30\% down to 350,000. This has happened for many reasons, including competition over land and water, but mainly due to poaching. ${ }^{11}$ According to the NGO National Parks Rescue, the situation is so severe that elephants have as little as 10 years till extinction. ${ }^{12}$ The same, according to them, goes for the rhino, which has been under severe pressure due to a dramatic increase in poaching between 2008 and 2015. The majority of rhino were already found in South Africa, and this is where poaching was concentrated. During research on the rhino poaching crisis between 2011 and 2016, I often heard dramatic discourses about how the rhino was going extinct, sometimes indeed supposedly within 5 or 10 years (Büscher 2016).

While rhinos have taken a heavy toll, the South African Private Rhino Owners Association in 2018 wrote that rhinos on private land "is a remarkable conservation success story." They saw the numbers of rhinos on private land rise from 4000 at the start of the poaching crisis in 2008 to well over 5000 in 2014 when the crisis reached its zenith. ${ }^{13}$ This again does not mean that rhinos are doing well across the continent, but it does show that extinction fears are not necessarily related to the actual probability of extinction. Similarly, while elephants

\footnotetext{
${ }^{8}$ https://cites.org/sites/default/files/eng/cop/18/inf/E-CoP18-Inf-060.pdf, accessed 25 February 2020.

${ }^{9}$ Idem.

10 https://www.iucnredlist.org/species/219/50649567; https://news.mongabay.com/2019/12/mountain-gorilla-censusreveals-further-increase-in-numbers/, accessed 27 February 2020.

${ }^{11}$ http://www.greatelephantcensus.com, accessed 27 February 2020.

12 https://www.nationalparkrescue.org, accessed 27 February 2020.

$13 \quad$ https://www.rhinoalive.com/white-rhino-on-private-and-communal-land-important-letter-and-questionnaire-to-bereturned-by-3-september-2018/, accessed 25 February 2020.
} 
are clearly under strain, the fact that very large herds remain in various parts of Southern Africa, and even stable or growing numbers in several countries, including South Africa, shows that it is not realistic to say that these animals will soon go extinct, even in the face of an overall decline (Louw et al. 2021). ${ }^{14}$

To highlight one last charismatic example, the cheetah (Acinonyx jubatus) is interesting because its habitat needs are particular. Again "dramatic declines" were noted in a major article published in 2016 (Durant et al. 2016). This assessment emphasized that cheetahs are reliant on large territories and cannot depend on protected areas alone. And since land-use change is happening so rapidly across Africa, "a different approach may be needed to halt declines outside PAs and reduce impacts of edge effects on populations inside PAs to maintain connectivity and secure long-term viability of populations across large multiple-use landscapes." Hence, "new policy, management, and financial tools are needed that promote coexistence between people and wildlife outside and adjacent to PAs" otherwise "the future of wide-ranging and highly threatened species, such as cheetah, is in doubt" (Durant et al. 2016: 532). For species like cheetahs that rely on large range areas, smaller private reserves may not be able to sustain viable populations in the long term (idem). And while an estimated total number of 7,000 cheetahs in the wild does not mean they are near-extinct, this is a clear case where worrying species decline is linked to rapidly changing land-use across the African continent. Moreover, like with other species, there are several subspecies of cheetah - four to be precise - of which some are more threatened than others (including the Asiatic cheetah found only in Iran).

What about less high-profile examples? Extinction is not just about charismatic mammals. In fact, it is precisely the opposite (Lees et al. 2020). But since many non-charismatic species are not well studied (if at all), species numbers become even more problematic. Some of the available literature does suggest that many lesserknown species, including plants, have high extinction risks (UNEP 2016; Stévart et al. 2019). Yet here too there are rarely linear stories that end only one way; indeed, even many smaller or lesser-known species can survive in specific pockets if these are well protected, including in private reserves. This seems to be the case for reptiles in South Africa, though, again, not for all reptile species (Tolley et al. 2019). The point here is that generic declines and specific increases of species populations are both part of a broader context of the political economy of conservation in Africa, with South Africa playing a specific, important role. A closer look at species growth in relation to the privatization of nature helps to illuminate this broader context and the role of South Africa.

\section{Species growth and the privatization of nature}

The private possession and use of wildlife, through hunting, tourism, estates, ranching, private reserves and more, is often seen as an antidote to species decline (Lindsey et al. 2009; Wilson 2016). In South Africa, this has a very particular and prominent history, as one of the most famous instances of this argument relates to the selling of rhinos to private owners in the 1960s and 1970s as part of the boosting of rhino numbers to save it from extinction (Player 2013). This effort, led by the famous conservationist Ian Player, is widely regarded as one of the biggest conservation successes of all time, and helped to build the argument that private possession of wildlife is seen as a solution to species decline. This point was often made by influential conservationists like Ian Player and continues to be repeated frequently. Take prominent game ranchers Pamela and Peter Oberem. According to them: "the principle of 'if it pays, it stays' once quoted by prominent South African conservationist Dr John Ledger, about the future of conservation in Africa, has proven to be correct" (Oberem and Oberem 2016: 10). As a result, since the 1960s, we have seen a steady growth of private possession, management and use of wildlife in South Africa and other countries in Southern Africa and beyond (Snijders 2012). Indeed, before we go into more detail about South Africa, it is important to note that this is not just a South African phenomenon, even though South Africa plays a crucial role in the wildlife economy of the continent as a whole.

One notable illustration of an organization that has made the de facto privatization of parks the core of their business model is the NGO African Parks Foundation (APF). ${ }^{15}$ APF now run 17 parks in 11 countries,

14

https://static1.squarespace.com/static/5304f39be4b0c1e749b456be/t/57c71f5fcd0f68b39c3f4bfa/1472667487326/GEC+R esults+Country+by+Country+Findings+Fact+Sheet_FINAL_8+26+2016.pdf, accessed 27 February 2020.

15 https://www.africanparks.org, accessed 2 March 2020. 
including in Niger, Chad, Central African Republic and elsewhere, which they do on a long-term lease basis from the respective governments. They claim that they are effective because they have 'pioneered' a publicprivate partnership model for African conservation, "whereby African Parks maintains the full responsibility and execution of all management functions and is accountable to the government, who is the owner and who determines the policy." 16 This is privatized management of public parks, with a strong emphasis on law enforcement and community engagement. According to APF, this has led to a sometimes-dramatic increase in wildlife, like for instance in the Majete reserve in Malawi:

Decades of lawlessness and poaching had seen the reserve's wildlife completely eradicated by the 1990s. This all changed in 2003, when African Parks assumed management of Majete, the first park to enter our portfolio. We immediately began to revive the park through a series of species reintroductions. Today, Majete is flourishing, so much so that wildlife is being moved to populate other parks and private reserves within the country. ${ }^{17}$

Next to APF, there are also many other private reserves and conservancies, like those in Laikipia county in Kenya, including the famous Ol Pejeta (home of the last northern white rhinos; see Bersaglio and Margulies 2021) and several public parks that are de facto private-run due to the almost complete take-over of foreign management, like in the Virunga National Park in the DRC (Marijnen and Verweijen 2016). ${ }^{18}$ In Southern Africa, countries like Botswana, Zambia and Namibia have also seen a rise in private reserves (Lindsey et al. 2009), which in some cases follow a long history of developing profitable, state-led wildlife economies (Mogende and Ramutsindela 2020). All this has resulted in sometimes spectacular species growth. On this basis, some analysts look to Southern Africa as an example to promote the privatization of nature elsewhere:

Lands that were formerly dedicated to domestic livestock enterprise have converted to wildlife conservation on a grand scale (...) and southern Africa has more wildlife than 100 years ago, which stands in contrast to the declining wildlife that is owned by the State elsewhere in Africa (...). Indeed, the policy has been so successful that populations of some species are increasing exponentially (...) and a collapse in prices and numbers is possible. (Wilson et al. 2016: 3)

The article is referring to the large-scale transition from productive agricultural farms to game farms and private nature reserves, of which there are now an estimated 12,000 in South Africa alone. ${ }^{19}$ As Brooks et al., also reflecting on this trend, note:

Over the past two decades, private game farms have become an increasingly dominant feature of the South African countryside. The driving forces behind this move by landowners from conventional agricultural operations to various forms of wildlife-based enterprise are complex, the result of a range of global economic imperatives intersecting with local socioeconomic pressures and concerns. Clearly one of the key drivers is tourism. (Brooks et al. 2011: 260)

As they further emphasize, private landowners "grasped the opportunity to benefit from the growing ecotourism-based leisure market" (idem: 261) and so further experimented with various forms of the use and private profiting of wildlife. As part of this process, species growth became an explicit goal, so encouraging

\footnotetext{
${ }^{16}$ https://www.africanparks.org/about-us/our-story/the-african-parks-model, accessed 2 March 2020.

${ }^{17}$ https://www.africanparks.org/the-parks/majete, accessed 2 March 2020.

18 The set-up of the Virunga park is complex and although it is a national park, the private Virunga Foundation holds a lot of power in the management set-up, which Marijnen and Verweijen (2016) argue, leads to a major emphasis on marketization and green militarization of the park.

${ }^{19}$ https://cites.org/sites/default/files/eng/cop/18/inf/E-CoP18-Inf-060.pdf, accessed 28 February 2020. This number means a rapid growth from the 399 properties devoted to wildlife in 1974 (Snijders 2012: 92).
} 
wildlife ranching as a related industry (Lindsey et al. 2009; Oberem and Oberem 2016). As noted, this became so successful that new problems started to occur:

Legislative changes during recent decades resulted in a massive shift away from livestock towards game ranching in southern Africa, resulting in significant increases in the abundance and distribution of many wildlife species. However, there are problems associated with game ranching from a conservation perspective, including persecution of predators, overstocking, introductions of exotic species and genetic manipulation of 'huntable' species (Lindsey et al. 2009: 99).

In response, the authors suggest that adjoining private reserves should consider forming conservancies to overcome some of these problems. Conservancies are multiple, conjoined properties without internal fencing and can so, according to Lindsey et al (2009), better balance the numbers of species and be more tolerant of predators. This in turn, they and others argue, is good for ecotourism and hunting, which may stimulate local community development and 'decent jobs' as well (idem; Oberem and Oberem 2016: 11). Brooks et al. (2011), who have looked into this premise, are more skeptical and note many problems related to community development and jobs in the wildlife sector. This is an important issue I will come back to below. The remainder of this section first relates how and why the South African government aims to further stimulate the privatization of wildlife through the development of a broader 'biodiversity economy.'

South Africa is both highly biodiverse and the most developed country in the continent, giving it particular abilities and possibilities that allow it to further profit from wildlife (Kamuti 2015). It is 'welldeveloped' overall, and contains tourism infrastructures and many other (tourism) attractions to make it an appealing place to visit for many western and other tourists (Van Amerom and Büscher 2005). ${ }^{20}$ The private wildlife industry has been strong for a long time and gaining confidence due to its growth and success. It has also led its representatives to put much pressure on the South African government to come with an enabling policy framework that would allow them to grow and develop further, become more profitable and so contribute to the South African economy and job-creation (Snijders 2012). ${ }^{21}$ One of the responses has been the launch and development of a general policy of encouraging the growth of the South African 'biodiversity economy.' In 2016, this led to the launch of the National Biodiversity Economy Strategy (NBES; DEA 2016), which further develops distinct bioprospecting and wildlife economies. I will focus on the latter, about which former Environment Minister Molewa remarks that (DEA 2016: iii):

Over the period 2008-2013, the total Wildlife Industry market has grown by more than $14 \%$ per year. To understand the future growth potential of this sector, it is important to first understand how this growth was comprised. This growth comprised an average annual growth exceeding $6 \%$ in domestic hunting, a decrease in international hunting, and an exponential growth in live auction sales. It is likely that the increase in the domestic hunting market would continue. International hunting has reduced since 2008, evidently as a result of the global economic crisis, and thus holds a very significant growth potential as the international economy stabilises and grows, at least on par with domestic hunting. The growth in live auction sales has experienced unprecedented growth over the past 5 years, mostly likely driven by new investments in the Wildlife Industry. It is likely that this market segment will stabilise and that annual growth will thus also stabilize at normal levels. Based on these figures, it is likely that the consolidated

\footnotetext{
${ }^{20}$ The numbers of non-western tourists, including from the middle east, India and other parts of Asia, but also elsewhere, has increased over the last years, though not in large numbers. See: https://www.southafrica.net/gl/en/corporate/page/international-tourist-arrivals-report, accessed 20 July 2021. All numbers have seen dramatic declines in 2020 and 2021 due to the SARS-CoV-2 pandemic.

21 This was very visible, for example, during the 2016 CITES conference of parties in Johannesburg, attended by the author, where private wildlife spokespeople were very active in pushing discourses to get the government to act to facilitate and enable the industry.
} 
Wildlife Industry has the potential to experience a weighted average annual growth rates between $4 \%-14 \%$ per year over the next 14 years.

What is important about the 97-page NBES is that it is not just an overarching government strategy for the biodiversity sector. Rather, it aims to transfer this entire sector into a broader economy across the agricultural, eco-tourism and conservation domains that is supposed to play an important part in the South African economy as a whole (DEA 2016: 18). Moreover, it aims to build income-earning opportunities for poor, rural populations and so tie significant segments of society into a broader economy dependent on biodiversity and (the growth of) wildlife. This is clear from the executive summary (DEA 2016: v): "NBES has set an industry growth goal stating that by 2030, the South African biodiversity economy will achieve an average annualised GDP growth rate of $10 \%$ per annum. This envisioned growth curve extends into the year 2030 and is aligned to the efforts of the country's National Development Plan, Vision 2030." To achieve this and ensure poverty reduction and job creation, the strategy has a strong vision for turning rural marginalized people into neoliberal entrepreneurs, as emphasized by Minister Molewa's forward (DEA 2016: iii-iv):

This Strategy will not only assist South Africa's transition to Green Economy, but will also play a bigger role for livelihoods in job creation and poverty reduction, especially for rural communities, as most of the indigenous biological resources surrounds these communities. This Strategy will also play a major role in the transformation of the economy by motivating marginalised individuals to start their own biodiversity-based enterprises, as well as enhancing the entrepreneurial spirit of current players in the sector, thus, creating an appreciable and sustainable economic presence.

As so often, this neoliberal discourse and the grand 'economy of expectations' attached to it are starkly different from the realities they purport to intervene in and transform. Below, I will touch on several of these. For now, it is important to emphasize that investment in and pressure on the sector to grow is expected to continue to increase tremendously in the coming decade. Indeed, the government and the 'wildlife forum' it has established, have already gone all out to organize several 'biodiversity economy indaba's' (meetings) ${ }^{22}$, publish research and strategy documents, bring players together and develop marketing and publicity materials, including to convince 'marginalized individuals to start their own biodiversity-based enterprise', as illustrated in Figure 1.

Whether or how this wildlife economy works out and meets the expectations, especially given the dramatic disruptions to 'conservation business as normal' due to the SARS-CoV-2 pandemic, is an important question I will return to. Important for now, however, is that when an entire economy is being built on the premise of tradable, visible, exploitable and augmentable wildlife, it must ensure that this wildlife is indeed available and abundantly so. Short of a (perhaps not unthinkable) disaster like a super virus that kills most wildlife, it therefore seems likely that there will be a lot of investment in ensuring not just the survival of species, but indeed the growth and adequate population management of species, including on genetic levels. This became clear in July 2020 when the South African Department of Environment, Forestry and Fisheries announced a 'reprioritization' of its budgets for a 'nature-based post Covid-19 recovery.' As the Minister announced, because of the "the important role that the biodiversity economy plays in the country's development plan", substantial investments are made into the sector to ensure the 'sustainability of our protected areas' as well as "the future sustainability of our contribution to nature-based tourism and its longer term employment potential."23 A year later, in May 2021, the Minister concretized the expected results: "The Biodiversity Economy is expected to create 110,000 new jobs by 2030 and contribute an additional R47 billion to GDP."24

\footnotetext{
22 https://www.environment.gov.za/event/deptactivity/3rdbiodiversity_economyindaba, accessed 28 February 2020.

23 See https://www.environment.gov.za/mediarelease/creecy_covid19revised_budgetvote202021, accessed 19 August 2020.

${ }^{24}$ https://www.gov.za/xh/node/806695, accessed 21 July 2021.
} 


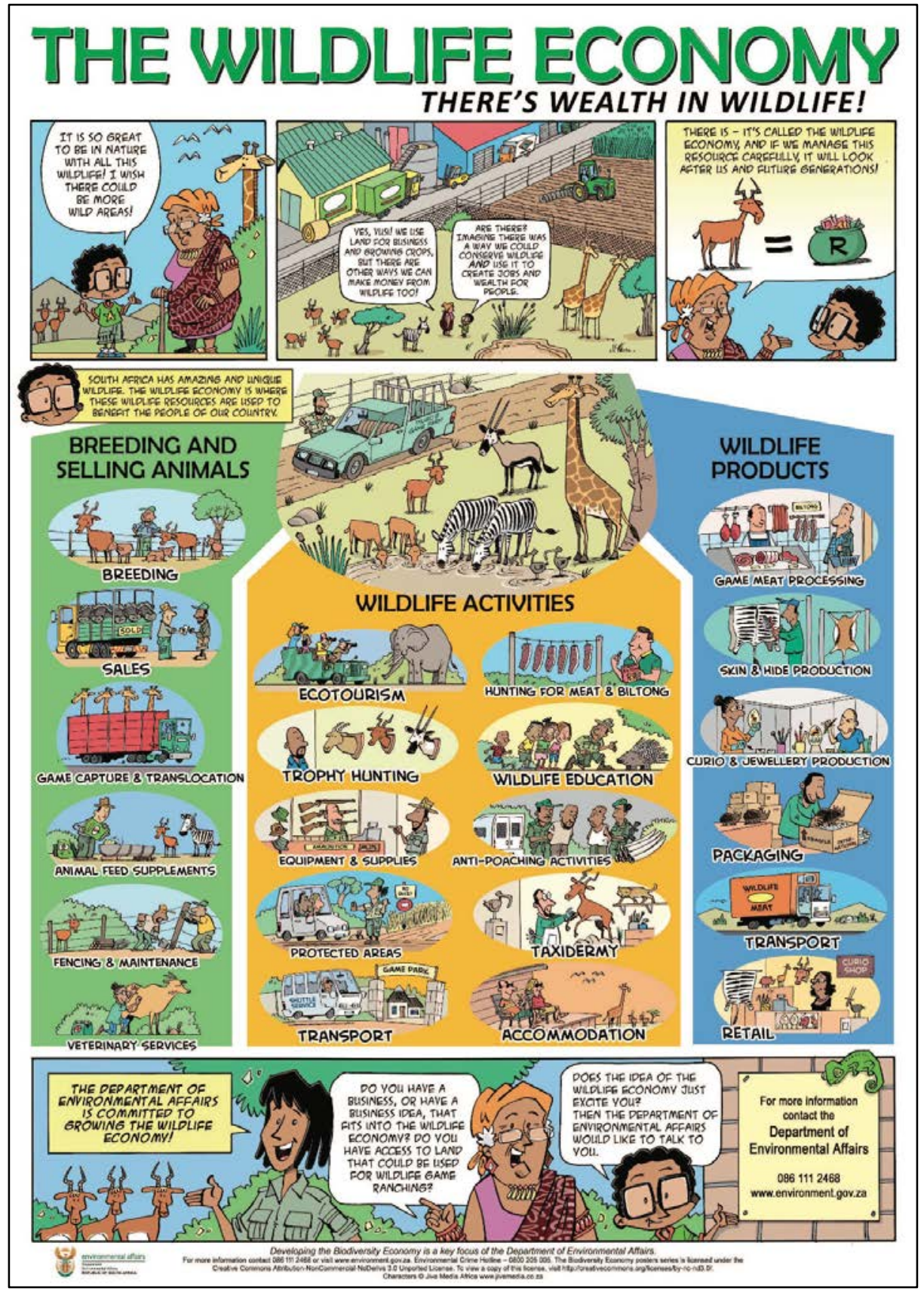

Figure 1: DEA leaflet on the wildlife economy. Source:

https://www.environment.gov.za/event/deptactivity/3rdbiodiversity_economyindaba

Hence, instead of tempering high expectations in the face of potential major disruptions, the SARS-CoV2 crisis is used to further intensify the pressure on the biodiversity economy. Consequently, it stands to be assumed that the biopolitics of wildlife in South(ern) Africa will also intensify drastically, and that this may indeed lead to thriving and growing wildlife populations in many different reserves in the region (with potential knock-on effects following the translocation of animals from South Africa to reserves in other parts of Africa). 
At the very least, it will be highly unlikely that the major charismatic species this entire industry depends on, including the lion, elephant, giraffe, rhino and others, will go extinct soon. What seems more likely is that they will become more concentrated into distinct regions that contain highly 'stocked', intensely managed reserves. One of the most prominent of such regions is the Hoedspruit area in the Greater Kruger region.

\section{Hoedspruit: the wildlife haven}

Hoedspruit is a small village west of the Kruger National Park (Figures 2 and 3). A quiet backwater only 20-25 years ago, Hoedspruit has grown rapidly into the center of the most important wildlife economy region in South Africa (Thakholi 2021b). The town calls itself a 'wildlife haven' and is surrounded by private nature reserves and smaller, so-called 'wildlife estates': fenced lifestyle estates where one can live surrounded by wildlife.

It is these wildlife estates and surrounding private reserves and its proximity to the Kruger Park that has allowed the town to grow massively and rapidly. ${ }^{25}$ Different types of people, including investors, pensioners, wildlife professionals but also families, have purchased houses in these estates and also started investing in Hoedspruit, including building schools, restaurants, shops and other infrastructure, which drew further development and people. ${ }^{26}$ Most major South African real-estate companies have offices in Hoedspruit and advertise 'environmental', 'safe' and 'peaceful' living in a town with all necessary modern amenities, including a small airport. ${ }^{27}$ Still, the major attraction for the region is how the Kruger National Park works as a 'capitalmultiplier.' Take Blyde Wildlife Estate, one of several wildlife estates close to Hoedspruit:

Only $65 \mathrm{~km}$ from Blyde Wildlife Estate is Kruger Nationalpark [sic], which not without reason is South Africa's proudest and main visitor attraction. With its $20,000 \mathrm{~km}^{2}$ we are not only talking about the country's largest safari area, but also the largest game reserve in the world, which can muster the largest concentration of mammals including approx. 8,000 elephants, 2,500 white rhinos, 13,000 gnus and 900 sable antelopes just to mention a few. Here we are talking about the world's largest interconnected natural areas, where the wildlife can live undisturbed by man under protected conditions. ${ }^{28}$

While these claims are hard to verify and probably quite unsubstantiated, the broader point for this article is not whether these numbers about species match exactly with reality. It is rather that the dense and growing numbers of wildlife reserves and estates, the large ecotourism sector and the very lively wildlife ranching sector in the area all make for a large focus on species breeding and growth in species numbers. Indeed, in several interviews, it was explicitly mentioned that many reserves are more about stocking and sometimes even 'overstocking', than about conservation. ${ }^{29}$ One estate agent even referred to this as the 'dark side' of the estates. This 'dark side' of (over)stocking is specifically related to the above-mentioned charismatic species as well as the ungulates they live with and prey on. This again shows that in selected pockets of the continent, strong species growth is not only happening but the basis for a broader economy more generally. It also further increases the pressure to ensure that at least the main charismatic African savannah species will not go extinct.

Due to all these factors, it is also clear that the Hoedspruit area, as part of the Greater Kruger region, is critical within the broader South African Wildlife Economy Strategy (DEA 2016: 9). It is where much capital is based, where different activities come together and from where many important players in the wildlife

\footnotetext{
25 These wildlife estates are part of a larger trend in South Africa of the development of 'eco-estates' around major urban centres that also focus on nature-based lifestyles for 'largely white elites' (Ballard and Jones 2011).

${ }^{26}$ Interview real-estate developer, 11 January 2017, Hoedspruit, South Africa. See also Thakholi $2021 \mathrm{~b}$.

${ }^{27}$ See, for example, https://www.remax.co.za/property/for-sale/south-africa/limpopo/hoedspruit/, accessed 4 March 2020.

${ }^{28}$ http://www.blyde.dk/the_area.html, accessed 23 April 2017.

${ }^{29}$ Interview estate agent, 10 January 2017, Hoedspruit, South Africa. Oberem and Oberem (2016) also talk about (over)stocking being an issue in wildlife ranching, though others question the extent to which this takes place as they believe this would be an example of 'bad management' (interview by Dr. Stasja Koot with wildlife consultant and Hoedspruit resident, 10 November 2017). Thanks to Dr. Koot for permission to refer to this interview.
} 
economy operate. In the next Section, I will reflect on what this means in terms of the broader wildlife geographies and the question of extinction in Africa as a whole. For now, I want to discuss what the article alluded to several times already: whether the booming wildlife economy can live up to its social expectations, especially in relation to community development and upliftment.

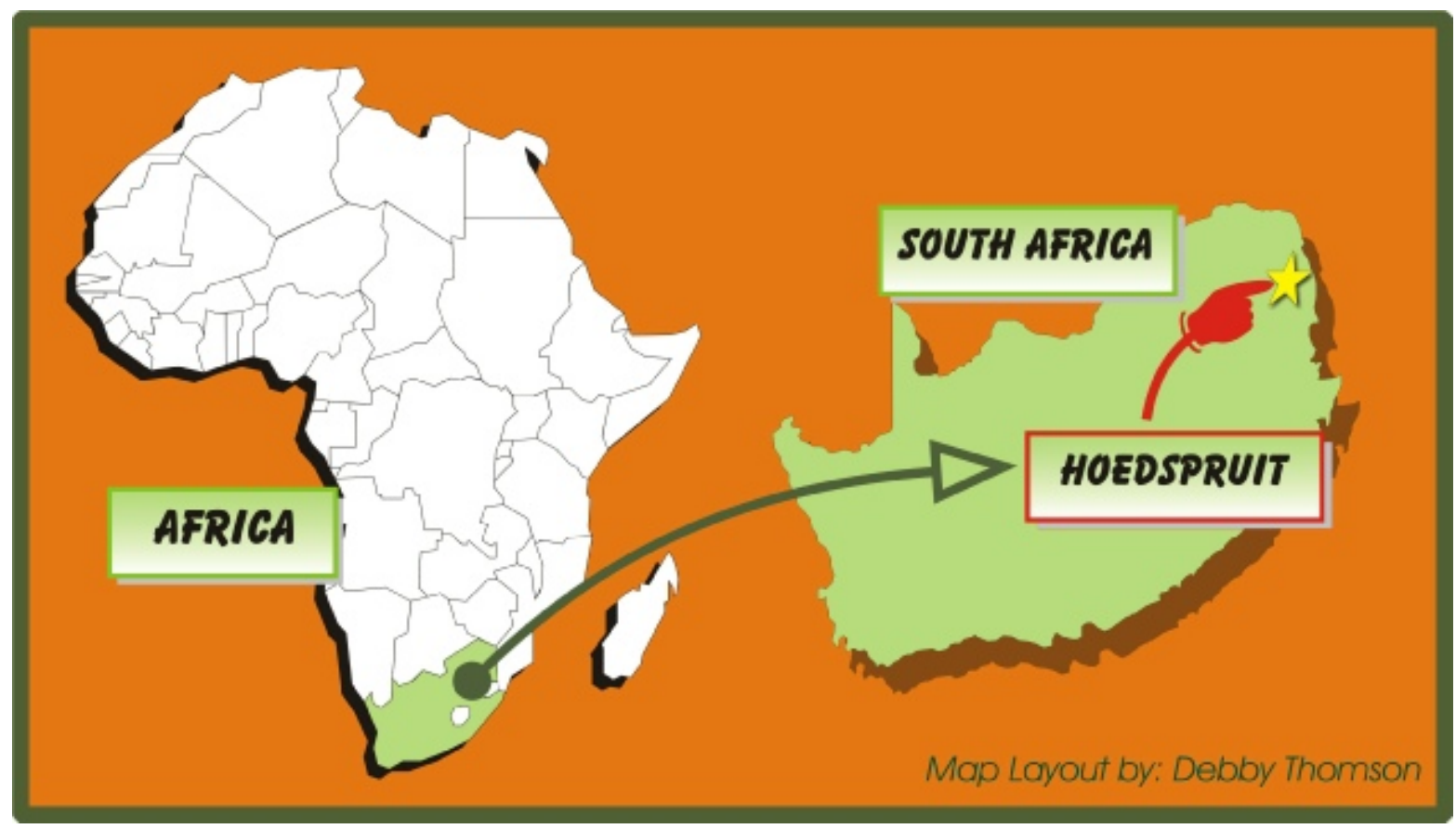

Figure 2: Hoedspruit location overview. Source: http://www.hoedspruit.co.za/contextual.html

Based on research since 2016 in this region by myself and colleagues, especially the research done by Lerato Thakholi (see her article in this special issue: Thakholi 2021a; also Thakholi 2021b), it is clear that the social situation in the Hoedspruit area is dire and highly unequal in racialized but also gendered ways. As Thakholi details in her article, unemployment is high (higher than the national average), the general forms of labour and jobs in the wildlife economy are poorly paid, highly insecure and come with much pressure and anxiety. One major source of this anxiety is that laborers in the private wildlife industry have started to be regularly polygraphed because of measures to curb rhino poaching, which escalated in the late 2000s (Thakholi 2021b: 7). All this comes within a context that is highly skewed in favor of white investors and national or global elites vis-à-vis local black people who have been historically dispossessed (Thakholi 2021a; Koot 2021; see also Mogende and Ramutsindela 2020, for a similar argument about Botswana).

The critical element undergirding these dynamics is (access to) land. All the land around and in Hoedspruit town is private and mostly in the hands of wealthy whites. This was mentioned, for example, by a staff officer from the local municipality:

The only challenge is land; the moment that there is land, the town can grow; the reason why we don't have land is that the whites don't want to sell the land, they want to control the town; Hoedspruit is unique in that there is no township settlement, but if we would have that we could promote work much more; but also for people to work where they live and vice-versa; and then they don't have to take the buses, which also impact the environment. And the thing of traveling also causes lots of accidents; so it really has a negative impact on people. ${ }^{30}$

\footnotetext{
${ }^{30}$ Interview Staff Officer Maruleng Municipality, 12 May 2017, Hoedspruit, South Africa
} 
As this staff officer also mentions, there is no space for low-cost housing, which means that most of the people who work in and around Hoedspruit's wildlife economy have to be bussed in and out every day from two former homeland areas called 'The Oaks and the Willows' and the Bushbuckridge area, both of which are about 30-40 km away. This leads to further insecurity, road safety hazards, as well as high transport costs for many laborers, which takes away from their already meagre salaries.

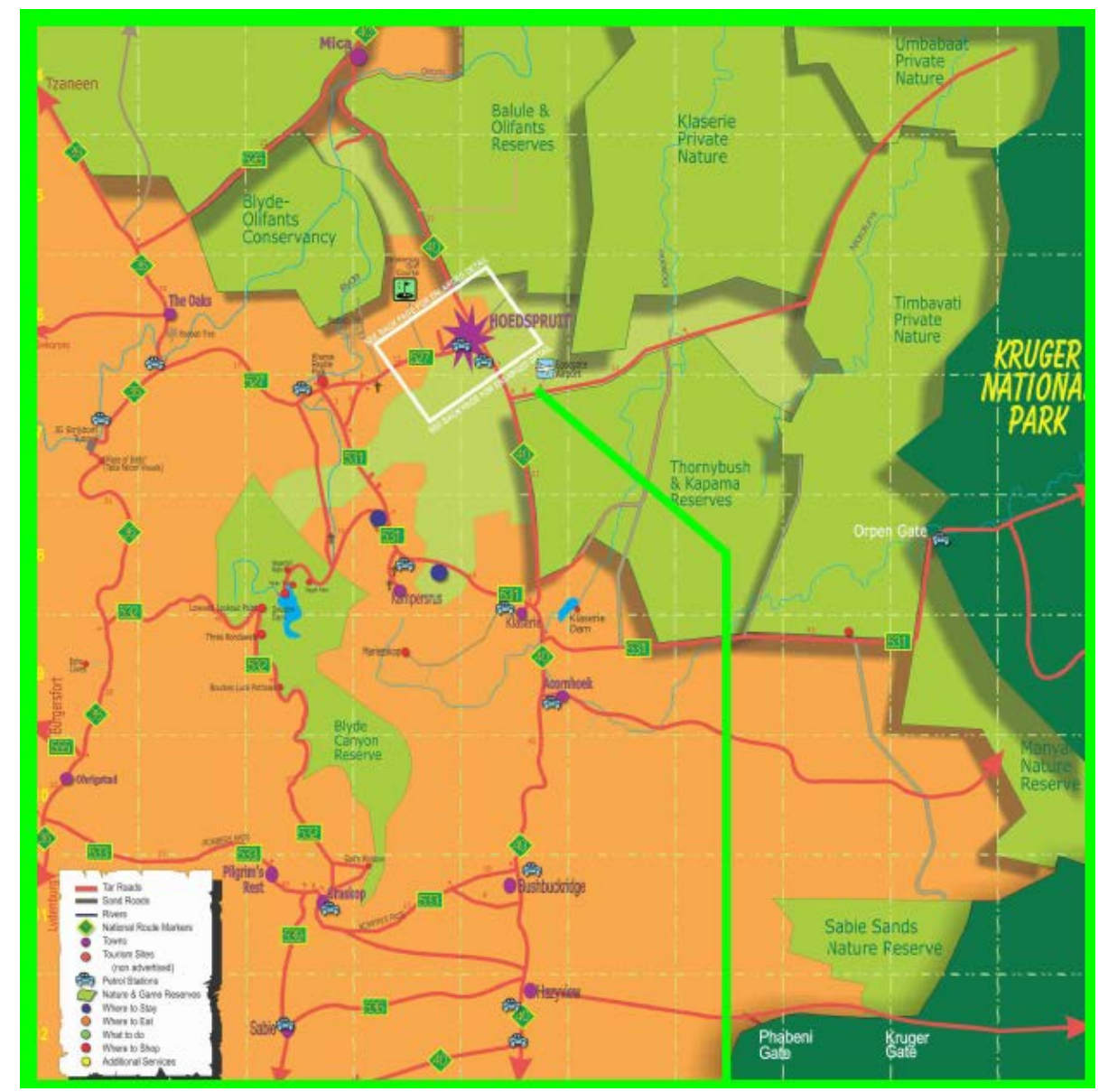

Figure 3: Hoedspruit location detail. Source: http://www.hoedspruit.co.za/recommended.html

The critical element undergirding these dynamics is (access to) land. All the land around and in Hoedspruit town is private and mostly in the hands of wealthy whites. This was mentioned, for example, by a staff officer from the local municipality:

The only challenge is land; the moment that there is land, the town can grow; the reason why we don't have land is that the whites don't want to sell the land, they want to control the town; Hoedspruit is unique in that there is no township settlement, but if we would have that we could promote work much more; but also for people to work where they live and vice-versa; and then they don't have to take the buses, which also impact the environment. And the thing of traveling also causes lots of accidents; so it really has a negative impact on people. ${ }^{31}$

\footnotetext{
${ }^{31}$ Interview Staff Officer Maruleng Municipality, 12 May 2017, Hoedspruit, South Africa.
} 
As this staff officer also mentions, there is no space for low-cost housing, which means that most of the people who work in and around Hoedspruit's wildlife economy have to be bussed in and out every day from two former homeland areas called 'The Oaks and the Willows' and the Bushbuckridge area, both of which are about 30-40 $\mathrm{km}$ away. This leads to further insecurity, road safety hazards, as well as high transport costs for many laborers, which takes away from their already meagre salaries.

The situation is therefore quite desperate in the area, leading Thakholi (2021a; 2021b) to refer to this as a socio-economic crisis situation. Yet, many whites in the area do little to fundamentally change the situation. One influential real-estate mogul was blunt about this, stating in an interview: "we have the former homelands, Oaks and Willows and Bushbuckridge, where people stay and own land, so they want to return there, and don't really want to live in Hoedspruit, so this enables Hoedspruit to remain as it is, which is a good thing." ${ }^{32}$ Another example comes from Zandspruit wildlife estate, a more upmarket estate in Hoedspruit. Whilst doing a tour of the property with one of the developers, I was told that the owner got lucky in buying the property even though it could have been bought by the municipality, which ended up not happening. This, according to the developer, was very fortunate, because the other plan for the area was to develop low-cost housing, and this, according to him, "would have killed the town." He continued by saying that if the land would have been bought by the municipality, there would have been a massive influx of poor people and that it would have been a 'mess with too many houses' and 'chaos.' He concluded that it was fortunate that this did not happen. ${ }^{33}$

The skewed land ownership was a key issue throughout my research in the area, and how this stopped the municipality from providing housing for poorer segments of society, leading to a form of 'green apartheid' where social and racial divisions are extremely stark (Koot et al., in submission). This strong statement is further reinforced by research findings that indicated that the social benefits from the wildlife economy are deeply racially skewed and that there are few black 'entrepreneurs' able to develop significant businesses as per the DEA leaflet above, although there are obviously some. ${ }^{34}$ Most black entrepreneurs continue to depend on lowwage activities, like selling curios or other forms of informal labor. And while this does not mean that black entrepreneurs are (always) rejected, the ones able to move from marginalized and low-income activities to the center of the wildlife economy in the Hoedspruit area seem to be few.

All this should not be surprising, certainly not to those who study the broader South African postApartheid context, where dire social situations and inequalities continue to be rife, and have sometimes worsened in recent years (Von Schnitzler 2016; Marcatelli and Büscher 2019). It is also not surprising in the context of broader theories of uneven capitalist development (Harvey 2006; Smith 2008). One of the core elements of these theories is that capitalist development is characterized by social and other forms of unevenness, and that these map onto other (racialized, gendered, historical) forms of unevenness. In the case of the wildlife economy in the Hoedspruit area, this leads to a situation where the profitability of the wildlife economy is enhanced by the presence of a large surplus population of marginalized people, desperate for any form of income. Even worse, as I have shown, influential segments of the white wildlife economy elite deliberately try to keep it that way. Yet this is but one element of the broader intensification of uneven wildlife geographies in Africa.

\section{The intensification of uneven wildlife geographies}

How do the above empirical dynamics fit within a broader political ecology of wildlife decline and extinction fears in the continent as a whole? I argue that these uneven dynamics are a logical part of the capitalist intensification of uneven wildlife geographies in Africa. This has two main elements: the overall push for the further integration of Africa into broader patterns of global capitalist development, and the role that wildlife and related sectors play in this. The first relates to the dynamic of the 'New Scramble for Africa' that many have written about (Carmody 2017) and that itself is an intensification of older colonial and postcolonial dynamics of exploitation of Africa and its resources (Rodney 1972; Büscher 2012; Mbembe 2016). These historical and

\footnotetext{
32 Interview real-estate developer, 11 January 2017, Hoedspruit, South Africa.

33 Participatory observation, Zandspruit estate, 30 August 2017, Hoedspruit South Africa.

${ }^{34}$ See, for example, https://hoedspruit.net/tours/wild-olive-tree-camp/, accessed 21 July 2021.
} 
contemporary global dynamics of accumulation are critical to place the ongoing 'New Scramble' in context, as argued by Ayers:

Integral to this worldwide strategy of accumulation have been profound changes in the social, technical and spatial organisation of capitalist production, encompassing three interconnected processes: firstly, manifold defeats of labour and the emergence of new chasmic levels of inequality; secondly, a shift to lean production and industrial restructuring; and thirdly, the spatial reorganisation of global capitalism and intensified processes of 'primitive accumulation' (...). It is in such interconnected processes, particularly the spatial reorganisation of global capitalism and intensified processes of primitive accumulation, the article contends, that the 'new scramble for Africa' is to be more adequately understood. (Ayers 2013: 237)

It follows that the ongoing scramble for Africa as part of the intensifying capitalist uneven development of the continent has major consequences for land use and for the environment, broadly defined. With increasing industrialisation, trade, infrastructural and general (though highly uneven) economic development across the continent, lands for conservation and species are under increasingly intense pressure. According to UNEP's 2016 regional assessment for Africa:

Major threats to biodiversity in Africa include habitat destruction, deforestation, habitat conversion and disturbances such as habitat fragmentation, overexploitation of some species, invasive alien species, pollution, and climate change and variability. Changes in land use and lack of appropriate land-use planning contribute to loss of habitats and biodiversity. Agricultural expansion (... ), establishment of settlements in biodiversity-rich ecosystems and sensitive areas, expansion of livestock into wildlife management areas, excessive collection of firewood and construction materials, and illegal exploitation of wildlife also contribute to biodiversity loss. Invasive alien species of both plants and animals are a serious threat to local biodiversity in the region/ (UNEP 2016: 78)

Similarly, the recent IPBES (2018: 249) assessment for Africa:

Africa's development outcomes for the coming decades will be determined by a number of drivers of change, and the policy changes adopted by African countries in response to changing world conditions (...). Cumulatively, these drivers are likely to create dramatic changes for the African continent and the global environment with which the continent interacts. Africa has some of the most abundant natural resources in the world, including its biodiversity. The continent's development trajectories are projected to increase impacts on ecosystems. Economic growth, through production and consumption chains, human settlements and infrastructure development, will be a key driver of change. Many states in Africa have a vision to become emerging economies in the coming decades. This is compounded by rapid population growth and urbanisation, policy and cultural changes, and global resource demand especially for food, energy, water and other extractives. With increasing raw material extraction for economic growth and weak institutional arrangements, countries in Africa are experiencing unprecedented rate of resource exploitation in recent time.

These two reports show in great detail how Africa's further and deepening integration into global accumulation processes, as well as choices made by African governments and people in this process, lead to massive environmental challenges and, indeed, threats to and decline of species. At the same time, the two reports also 
highlight the role that wildlife in Africa can play in further stimulating accumulation processes. The executive summary of the IPBES (2018: xii) for Africa starts paradigmatically in this regard:

Africa's extraordinary richness in biodiversity and ecosystem services, and wealth of indigenous and local knowledge, comprises a strategic asset for sustainable development in the region. Africa is the last place on Earth with a significant assemblage of large mammals. Africa has significant regional, subregional and national variations in biodiversity that reflect climatic and physical differences, as well as the continent's long and varied history of human interactions with the environment. This natural richness, accumulated over millions of years, coupled with the wealth of indigenous and local knowledge on the continent, is central to, and constitutes a strategic asset for, the pursuit of sustainable development in the region (emphasis added).

This discourse follows a long genealogy of 'African exceptionalism' discourses that sought to frame Africa's charismatic animal species as the basis upon which the continent can build its wealth and place in the global capitalist economy (Snijders 2012). Many of these discourses go further still, by focusing more on Africa's charismatic animals than its people. In fact: the latter are often even blamed for the decline of species (Hughes 2010; Büscher 2011). In all of this, the spectres of crisis and extinction are critical, for two important reasons. First, they legitimate outside intervention into Africa's wildlife conservation and geographies. Extinction fears urge and inspire action and intervention, often violently so (Adams 2004; Massé and Lunstrum 2016; Duffy et al. 2019). Second, crisis and extinction make Africa's charismatic animals and ecosystems even more valuable. Extinction fears, in this logic, are very useful, something that Graham-Rowe (2011: s103) also points at:

Perhaps the most disturbing notion is the prospect that people might trade in endangered animals as a means of "investing in extinction." This is the idea that by actively buying up and stockpiling rare animal parts, one can not only push up the price, but also encourage further poaching that will eventually force the species into extinction. In cold-blooded business terms it makes an awful lot of sense, says John Scanlon, secretary-general of CITES in Geneva, Switzerland. "If something is rare it becomes more attractive," he says. "And the rarer something is, the more valuable it becomes."

According to this same logic, the private possession or commodified management of conservation spaces and its (over)stocking of species may actually benefit from an overall decline of charismatic species across the continent as a whole. As the number of charismatic species declines across the continent, it increases the value of well-stocked, privately conserved lands, providing their owners with unique sources of profit and revenue. In other words, the capitalist intensification of uneven wildlife geographies in Africa sits logically in between (over)stocking and extinction; it is the fear and possibility of the latter that makes the former so valuable. The paradoxical consequence is that actual extinction is not likely to happen in the foreseeable future for most charismatic African species, though it does not mean that their long-term future is certain either. In the conclusion I reflect and speculate on why this is so.

\section{Conclusion}

In this article I have brought together two recent trends in conservation debates and realities in Africa: the increasingly visible decline of charismatic species such as the rhino, elephant, cheetah, lion, giraffe and others and the less visible simultaneous growth of wildlife species, most notably through the (over)stocking of private reserves. One of the main points I have stressed is that the dramatic extinction fears and discourses that surround African charismatic animals are not just often exaggerated, but that they play a crucial role in the 
rendering valuable of the private exploitation of these same animals. ${ }^{35}$ This may also mean that most conservation players involved in the privatization of wildlife and the building of broader 'wildlife economies' have little incentive to question the rapid, uneven integration of Africa into the global capitalist economy. They may, like the IPBES and UNEP reports, lament the unfortunate social and environmental effects that this integration has, but not question its fundamental legitimacy or even its necessity.

To the contrary: they may even further emphasize the necessity of uneven development through the full integration of Africa into global capitalism so that other countries and regions may become more like South Africa, where capital believes it can manage the problems that bestow Africa's charismatic animals. In this neoliberal discourse of seeing challenges as 'opportunities', the decline of species in many parts of Africa due to large-scale land-use change is precisely the argument that is used to stimulate further privatization of wildlife and a concomitant neoliberalization of conservation. Yet this does not mean that the actual consequences of this integration and its detrimental social and environmental effects can remain hidden, even though private wildlife conservation is remarkably good at this (Thakholi 2021a). As Adams and Hutton (2007: 165) stated some time ago, "global discourses of extinction bear directly on local issues of rights and human welfare." In the case of the Hoedspruit area, the socially detrimental costs of the booming wildlife economy were not just right under the surface, but indeed underpin the entire edifice. Besides the moral and social horrors of these costs themselves, this renders the edifice very socially unstable for the longer term. This also shows that my argument in this article is not simply that unevenness is 'spatial.' Besides the incredible spatial unevenness in the extinction of species, with extinction in certain parts mirrored by abundance in other parts of Africa, the unevenness is social and political as well.

A similar argument could be advanced for the environmental costs of the further capitalist integration of Africa into the global political economy. While this may stimulate both the decline and the growth of species through a reshuffling of uneven wildlife geographies across the continent, it is not obvious that this is a stable long-term configuration. To the contrary, it seems remarkably unstable in myriad ways, including by taking into account the specter of climate change. All this, pace Harvey (2014: chapter 16), does not mean that we can or should expect a generic environmental collapse at some point soon in Africa. It does mean that the highly contradictory and ironic trends in wildlife conservation in Africa may intensify for quite a while to come. Whether and how these will at some point lead to broader tipping points that lead to the extinction of some species is uncertain and cannot be ruled out. But more likely in the short to medium-term, according to my analysis, might be a process of uneven degradation and destruction amid pockets of the exact opposite. The dangers in this more nuanced picture are perhaps not 'spectacular' yet therefore arguably more worrying. They signal the further development and intensification of a deeply unsustainable and crisis-prone constellation that is both highly conducive and vulnerable to major disruptive events. The SARS-CoV-2 pandemic that is far from over at the time of writing (August 2021) is but one and arguably relatively mild example of this.

Coming to grips with these dangers and their relations to extinction processes is critical. To do so, the further development of a political ecology of extinction is necessary: one that takes extinction processes seriously, but as part of a critique of broader processes and histories of uneven capitalist development.

\section{Bibliography}

Adams, W.M. 2004. Against extinction: the story of conservation. London: Earthscan.

Adams, W.M. and J. Hutton. 2007. People, parks and poverty: Political ecology and biodiversity conservation. Conservation and Society 5(2): 147-183.

Ayers, A.J. 2013. Beyond myths, lies and stereotypes: The political economy of a 'New Scramble for Africa', New Political Economy 18(2): 227-257.

Balding, M. and K.J.H. Williams. 2016. Plant blindness and the implications for plant conservation. Conservation Biology 30(6): 1192-1199.

\footnotetext{
35 To be sure, this argument stands in strong contrast to forms of 'extinction denial', which I explicitly reject (see Lees et al., 2020).
} 
Ballard, R. and G. Jones. 2011. Natural neighbors: Indigenous landscapes and eco-estates in Durban, South Africa. Annals of the Association of American Geographers 101(1): 131-148.

Barnes, M., I. Craigie, L. Harrison, J. Geldmann, B. Collen, S. Whitmee, A. Balmford, N. Burgess, T. Brooks, M. Hockings and S. Woodley. 2016. Wildlife population trends in protected areas predicted by national socio-economic metrics and body size. Nature Communications 7(12747): 1-9.

Barnosky, A., N. Matzke, S. Tomiya, G. Wogan, B. Swartz, T. Quental, C. Marshall, J. McGuire, E. Lindsey, K. Maguire, B. Mersey, and E. Ferrer. 2011. Has the Earth's sixth mass extinction already arrived? Nature 471: 51-57.

Bauer, H., G. Chapron, K. Nowell, P. Henschel, P. Funston, L. Hunter, D. Macdonald and C. Packer. 2015. Lion (Panthera leo) populations are declining rapidly across Africa, except in intensively managed areas. Proceedings of the National Academy of Sciences 112(48): 14894-14899.

Bauer, H., G. Chapron, K. Nowell, P. Henschel, P. Funston, L. Hunter, D. Macdonald, S. Dloniak and C. Packer. 2016. Reply to Riggio et al: Ongoing lion declines across most of Africa warrant urgent action. Proceedings of the National Academy of Sciences 113(2): E109.

Bersaglio, B. and J. Margulies. 2021. Extinctionscapes: Spatializing the commodification of animal lives and afterlives in conservation landscapes. Social \& Cultural Geography. Online first.

Büscher, B. 2011. The neoliberalisation of nature in Africa. In: T. Dietz, K. Havnevik, M. Kaag \& T. Ostigard (eds.). New topographies of power? Africa negotiating an emerging multi-polar world. Leiden: Brill.

Büscher, B. 2012. The political economy of Africa's natural resources and the 'Great Financial Crisis'. Tijdschrift voor Economische en Sociale Geografie 103(2): 136-149.

Büscher, B. 2016. "Rhino poaching is out of control!" Violence, race and the politics of hysteria in online conservation. Environment and Planning A 48(5): 979-998.

Büscher, B. and R. Fletcher. 2015. Accumulation by conservation. New Political Economy 20(2): 273-298.

Büscher, B. and M. Ramutsindela. 2016. Green violence: Rhino poaching and the war to save Southern Africa's Peace Parks. African Affairs 115(458): 1-22.

Büscher, B., R. Fletcher, D. Brockington, C. Sandbrook, W. M. Adams, L. Campbell, C. Corson, W. Dressler, R. Duffy, N. Gray, G. Holmes, A. Kelly, E. Lunstrum, M. Ramutsindela, K. Shanker. 2017. Half-earth or whole earth? Radical ideas for conservation and their implications. Oryx 51(3): 407-410.

Carmody, P. 2017. The new scramble for Africa. Second edition. London: Polity.

Child, B., ed. 2004. Parks in transition. London: Earthscan.

Ceballos G., P. Ehrlich, A. Barnosky, A. García, R. Pringle, T. Palmer. 2015. Accelerated modern humaninduced species losses: Entering the sixth mass extinction. Science Advances 1, 5.

Clements, H. and G. Cummings. 2016. Positives and pathologies of natural resource management on private land-conservation areas. Conservation Biology 31(3): 707-717.

Craigie, I., J. Baillie, A. Balmford, C. Carbone, B. Collen, R. Green and J. Hutton. 2010. Large mammal population declines in Africa's protected areas. Biological Conservation 143: 2221-2228.

Davies, T. A. Cowley, J. Bennie, C. Leyshon, R. Inger, H. Carter, B. Robinson, J.P. Duffy, S. Casalegno, G. Lambert and K. Gaston. 2018. Popular interest in vertebrates does not reflect extinction risk and is associated with bias in conservation investment. PLoS ONE 13(9): e0203694.

Deacon, F. and A. Tutchings. 2019. The South African giraffe Giraffa Camelopardalis giraffa: a conservation success story. Oryx 53(1): 45-48.

Department of Environmental Affairs. 2016. National Biodiversity Economy Strategy (NBES). Pretoria: Department of Environmental Affairs.

Di Marco, M., O. Venter, H.P. Possingham and J.E. Watson. 2018. Changes in the human footprint drive changes in species extinction risk. Nature Communications 9(4621): 1-9.

Donaldson, M.R., N.J. Burnett, D.C. Braun, C.D. Suski, S.G. Hinch, S.J. Cooke and J.T. Kerr. 2016. Taxonomic bias and international biodiversity conservation research. FACETS 1: 105-113. 
Driver, A., F. Mukhadi and E.A. Botts. 2019. An initial assessment of biodiversity-related employment in South Africa. Working Article 201902. DPRU, University of Cape Town.

Duffy, R., F. Massé, E. Smidt, E. Marijnen, B. Büscher, J. Verweijen, M. Ramutsindela, T. Simlai, L. Joanny and E. Lunstrum. 2019. Why we must question the militarisation of conservation. Biological Conservation 232: 66-73.

Durant, S., N. Mitchell, R. Groom, N. Pettorelli, et al. 2016. The global decline of cheetah Acinonyx jubatus and what it means for conservation. Proceedings of The National Academy of Sciences 114(3): 528-533.

Dures, S., C. Carbone, A. Loveridge, G. Maude, N. Midlane, O. Aschenborn and D. Gottelli. 2019. A century of decline: loss of genetic diversity in a southern African lion-conservation stronghold. Biodiversity Research 25: 870-879.

Fletcher, R., W.H. Dressler, Z. Anderson and B. Büscher. 2019. Natural capital must be defended: Green growth as neoliberal biopolitics. Journal of Peasant Studies 46(5): 1068-1095.

Fletcher, R., B. Büscher, K. Massarella and S. Koot. 2020. Close the Tap! COVID-19 and the need for Convivial Conservation. Journal of Australian Political Economy 85: 200-211.

Gordon, E.R., N. Butt, H. Rosner-Katz, A.D. Binley and J.R. Bennett. 2019. Relative costs of conserving threatened species across taxonomic groups. Conservation Biology 34(1): 276-281.

Graham-Rowe, D. 2011. Endangered and in demand. Nature 480: s101-s103.

Harvey, D. 2006. Spaces of global capitalism: towards a theory of uneven geographical development. London: Verso.

Harvey, D. 2014. Seventeen contradictions and the end of capitalism. London: Profile Books.

Hughes, D. 2010. Whiteness in Zimbabwe: race, landscape and the problem of belonging. Basingstoke: Palgrave.

Intergovernmental Science-Policy Platform on Biodiversity and Ecosystem Services (IPBES). 2018. The IPBES regional assessment report on biodiversity and ecosystem services for Africa. Bonn: IPBES.

Intergovernmental Science-Policy Platform on Biodiversity and Ecosystem Services (IPBES). 2019. Global assessment report on biodiversity and ecosystem services. Bonn: IPBES.

Isbell, F., A. Gonzalez, M. Loreau, J. Cowles, S. Díaz, A. Hector, G.M. Mace, D.A. Wardle, M.I. O'Connor, J.E. Duffy, L.A. Turnbull, P.L. Thompson and A. Larigauderie. 2017. Linking the influence and dependence of people on biodiversity across scales. Nature 546: 65-72.

Kamuti, T. 2015. A critique of the Green Economy - approach in the wildlife ranching sector in South Africa. Africa Insight 45(1): 146-168.

Koot, S. 2021. Enjoying extinction: Philanthrocapitalism, jouissance and excessive 'environmentourism' in the South African rhino poaching crisis. Journal of Political Ecology 28: 804822. https://doi.org/10.2458/jpe.2984

Koot, S., B. Büscher and L. Thakholi. in press. Wildlife haven, green apartheid? Race, capital and logics of enclosure in South Africa's wildlife economy. Environment and Planning E

Lindsey, P., S. Romañach and H. Davies-Mostert. 2009. The importance of conservancies for enhancing the value of game ranch land for large mammal conservation in southern Africa. Journal of Zoology 277: 99-105.

Lindsey, P. J. Allan, P., Brehony, P., A. Dickman, A. Robson, C. Begg, H. Bhammar, L. Blanken, T. Breuer, K. Fitzgerald, M. Flyman, P. Gandiwa, N. Giva, D. Kaelo, S. Nampindo, N. Nyambe, K. Steiner, A. Parker, D. Roe, P. Thomson, M. Trimble, A. Caron, and P. Tyrell. 2020. Conserving Africa's wildlife and wildlands through the COVID-19 crisis and beyond. Nature Ecology and Evolution 4: 1300-1310.

Lees, A., C. Attwood, J. Barlow and B. Phalan. 2020. Biodiversity scientists must fight the creeping rise of extinction denial. Nature Ecology \& Evolution.

Louw, A.S., S. MacFadyen, S. Ferreira and C. Hui. 2021. Elephant population responses to increased density in Kruger National Park. Koedoe 63(1): a1660.

Mansfield, B. (ed.). 2008. Privatization: property and the remaking of nature-society relations. London: Wiley. 
Marcatelli, M. and B. Büscher. 2019. Liquid violence: the politics of water responsibilisation and dispossession in South Africa. Water Alternatives 12(2): 725-738.

Marijnen, E. and J. Verweijen. 2016. Selling green militarization: The discursive (re)production of militarized conservation in the Virunga National Park, Democratic Republic of the Congo. Geoforum 75: 274-285.

Massé, F. and E. Lunstrum. 2016. Accumulation by securitization: Commercial poaching, neoliberal conservation, and the creation of new wildlife frontiers. Geoforum 69: 227-237.

Mbembe, A. 2016. Critique of Black reason. Durham: Duke University Press.

Mogende, E. and M. Ramutsindela. 2020. Political leadership and non-state actors in the greening of Botswana. Review of African Political Economy 47: 399-415.

Nicholson, S.K., D.G. Marneweck, P.A. Lindsey, K. Marnewick and H.T. Davies-Mostert. 2020. A 20-year review of the status of African wild dogs (Lycaon pictus) in South Africa. African Journal of Wildlife Research 50: 8-19.

Noss, R.F., A.P. Dobson, R. Baldwin, P. Beier, C.R. Davis, D.A. Dellasala, J. Francis, H. Locke, K. Nowak, R. Lopez, C. Reining, S.C. Trombulak and G. Tabor. 2012. Bolder thinking for conservation. Conservation Biology 26(1): 1-4.

Oates, J. 1999. Myth and reality in the rainforest: how conservation strategies are failing in West Africa. Berkeley: University of California Press.

Oberem, P. and P. Oberem. 2016. The new game rancher. Queenswood: Briza.

Player, I. 2013. The White Rhino saga. Johannesburg: Jonathan Ball.

Powell, M.A. 2016. Vanishing America: species extinction, racial peril, and the origins of conservation. Cambridge, MA: Harvard University Press.

Snijders, D. 2012. Shifting species in South Africa: wildlife policy, rural consequences. PhD dissertation. Amsterdam: VU University Amsterdam, Ridderprint.

Sodikoff, G. (ed.). 2012. The anthropology of extinction: Essays on culture and species death. Bloomington: Indiana University Press.

Stévart, T., G. Dauby, P.P. Lowry, A. Blach-Overgaard, V. Droissart, D.J. Harris, B.A. Mackinder, G. E. Schatz, B. Sonké, M.S.M. Sosef, J.-C. Svenning and J.J. Wieringa and T.L.P. Couvreur. 2019. A third of tropical African flora is potentially threatened with extinction. Science Advances 5(11): eaax9444.

Thakholi, L. 2021a. The biopolitics of private conservation: jeopardizing labor and rhino to optimize capital? Journal of Political Ecology 28(1): 705-720. https://doi.org/10.2458/jpe.4764

Thakholi, L. 2021b. Conservation labour geographies: subsuming regional labour into private conservation spaces in South Africa. Geoforum 123: 1-11.

Tolley, K., J. Weeber, B. Maritz, L. Verburgt, M.F. Bates, W. Conradie, M.D. Hofmeyr, A.A. Turner, J.M. da Silva and G.J. Alexander. 2019. No safe haven: Protection levels show imperilled South African reptiles not sufficiently safe-guarded despite low average extinction risk. Biological Conservation 233: 61-72.

Republic of South Africa. 2014. South Africa's Fifth National Report to the Convention on Biological Diversity. Pretoria: Republic of South Africa.

Riggio, J., T. Caro, L. Dollar, S. Durant, A. Jacobson, C. Kiffner, S. Pimm and R. van Aarde (2015). Lion populations may be declining in Africa but not as Bauer et al. suggest. Proceedings of The National Academy of Sciences 113(2): E107-E108.

Rodney, W. 1972. How Europe underdeveloped Africa. Washington D.C.: Howard University Press.

Rose, D., T. van Dooren and M. Chrulew (eds.) 2017. Extinction studies: stories of time, death, and generations. New York: Columbia University Press.

UNEP. 2016. GEO-6 regional assessment for Africa. Nairobi, Kenya: United Nations Environment Programme.

Van Amerom, M. and B. Büscher. 2005. Peace Parks in Southern Africa: Bringers of an African renaissance? Journal of Modern African Studies 43(2): 159-182. 
Von Schnitzler, A. 2016. Democracy's infrastructure: Techno-politics and protest after apartheid. Princeton: Princeton University Press.

Wilson, E.O. 2016. Half-Earth: Our planet's fight for life. London: Liferight Publishing.

Wilson, G., M. Hayward and C. Wilson. 2016. Market-based incentives and private ownership of wildlife to remedy shortfalls in government funding for conservation. Conservation Letters 10(4): 485-492. 